\title{
Biomechanical Comparison of Three Treatments for Medial Malleolar Fractures
}

\section{Medial Malleol Kırıklarının Tedavisinde Kullanılan Üç Farklı Yöntemin Biyomekanik Olarak Karşılaștırılması}

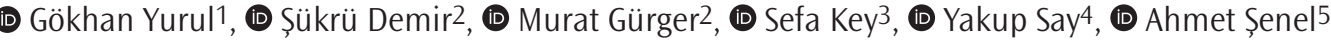

${ }^{1}$ Ceylanpınar State Hospital, Clinic of Orthopedics and Traumatology, Șanlıurfa, Turkey

${ }^{2}$ Firat University Faculty of Medicine, Department of Orthopedics and Traumatology, Elazı $\breve{g}$, Turkey

${ }^{3}$ Bingöl State Hospital, Clinic of Orthopedics and Traumatology, Bingöl, Turkey

${ }^{4}$ Munzur University Faculty of Engineering, Department of Mechatronics Engineering, Tunceli, Turkey

5Yıldırım Beyazıt University, Yenimahalle Training and Research Hospital, Clinic of Orthopedics and Traumatology, Ankara, Turkey

\begin{abstract}
Introduction: Ankle fractures are relatively common, accounting for $10 \%$ of all fractures in the skeletal system, and are the second most common lower extremity fractures after hip fractures. Here, we conduct a biomechanical comparison of three approaches-medial malleolar plate, handy tension band, and malleolar screw-for the treatment of transverse fractures of the medial malleolus.

Methods: Forty-two cow tibias, cut for human consumption and free from soft tissues, were procured from the butcher. In the medial malleoli, transverse fractures were created using a bone saw, and the bones were categorized into three equal groups: bones with fractures fixed using handy tension bands, malleolar screws, and medial malleolar plates. The samples were analyzed biomechanically using equipment prepared in the laboratory, including a test device that could apply tensile and transverse forces. The data collected were interpreted after conversion into force-displacement curves.
\end{abstract}

Results: When tensile force was applied, the medial malleolar plate demonstrated the greatest resistance to 2 $\mathrm{mm}$ displacement force and catastrophic damage force. No difference in resistance was found between the medial malleolar plate and handy tension band methods. When a transverse force was applied, the medial malleolar plate method demonstrated the greatest resistance to $2 \mathrm{~mm}$ displacement force.

Conclusion: The medial malleolar plate is an appropriate method for the treatment of transverse fractures of the medial malleolus, although further research is required to identify any potential disadvantages of this method.

Keywords: Medial malleolus, medial malleolar plate, handy tension band, malleolar screw

\section{öZ}

Amaç: İskelet sistemine ait tüm kırıklar içerisinde \%10 gibi bir oranla nispeten sıkgörülen ayak bileği kırıkları kalça kırıklarından sonra alt ekstremitenin en sık görülen ikinci kırık türüdür. Bu çalışmada, medial malleolün transvers kırıklarında medial malleol plağı, hazır gergi bandı, malleol vidası yöntemlerinin biyomekanik olarak karşılaştırılması amaçlanmıştır.

Yöntemler: Kasaptan, insan tüketimi için kesilmiş, yumuşak dokularından arındırılmış 42 adet inek tibiası temin edildi. Çalışma kapsamına alınan kemiklerin medial malleollerine kesici motor yardımıyla transvers kırıklar oluşturuldu ve her biri 14 kemikten olușan 3 gruba ayrıldı. Bu 3 gruptaki olușturulmuş olan medial malleol kırıkları hazır gergi bandı, malleol vidası, medial malleol plağı kullanılarak usulüne uygun tespit edildi. Örnekler laboratuvarda çekme kuvveti ve transvers kuvvet uygulayan test cihazında hazırlanmış aparatlar yardımıyla biyomekanik analize tabi tutuldu. Alınan veriler kuvvetdeplasman eğrilerine dönüștürülerek yorumlandı.

Bulgular: Çekme kuvvetinde medial malleol plağı yöntemi, 2 $\mathrm{mm}$ deplasman kuvveti ve katastrofik hasar kuvveti açısından diğer yöntemlere göre daha yüksek kuvvetlere dayanırken, dayanıklılık açısından hazır gergi bandı yöntemiyle arasında fark bulunamamıştır. Medial malleol plağı yönteminin çekme kuvvetinde malleol vidası yöntemine göre daha dayanıklı olduğu görülmüștür. Tranvers kuvvet uygulanan gruplarda $2 \mathrm{~mm}$ deplasman kuvvetinde medial malleol plağı yöntemi, hazır gergi bandı ve malleol vidası yöntemlerine göre daha yüksek kuvvetlere dayanabilmiștir. Transvers kuvvetlerde medial malleol plağı yöntemi, hazır gergi bandı ve malleol vidası yöntemlerine göre daha dayanıklı bulunmuştur.

Sonuç: Medial malleol plağı medial malleolün transvers kırıklarında uygulanabilecek bir yöntem olup bu yöntemin olası dezavantajları için yapılacak başka çalışmalara ihtiyaç olduğunu düşünmekteyiz.

Anahtar Kelimeler: Medial malleol, medial malleol plağı, gergi bandı, malleol vidası 


\section{Introduction}

Advances in and studies on fixation methods, secondary to the efforts to better understand ankle biomechanics, have helped change the treatment strategies for ankle fractures. The ultimate goal of treatments is to ensure a painless and functional ankle with the achievement of union. Surgical treatment is indicated when the anatomical integrity of the joint cannot be preserved using closed methods. Notably, studies have reported better functional outcomes with anatomical reduction $(1,2)$.

Medial malleolar fractures might either be isolated fractures or accompany other (bimalleolar or trimalleolar) fractures of the ankle. The fracture pattern is transverse in $57 \%$, oblique in $26 \%$, and vertical in $6 \%$ of all medial malleolar fractures. Transverse fractures are mostly associated with supination-external rotation type fractures, which are the most common type of fractures based on the Lauge-Hansen classification, as well as with trimalleolar fractures and syndesmosis injuries. In addition, these are injuries that cause instability in the ankle. Transverse fractures are usually located at the level of the tibial plafond $(3,4)$. Reportedly, open reduction-internal fixation is considered the standard treatment for unstable and displaced medial malleolar fractures $(5,6)$.

Currently, several fixation methods are being used for the surgical treatment of medial malleolar fractures. The present study makes a biomechanical comparison of three such fixation methods, handy tension band, malleolar plate, and malleolar screw approaches, for the treatment of transverse fractures of the medial malleolus.

\section{Methods}

This study was financially supported by the university scientific research project. It used 28 malleolar screws (TST, İstanbul, Turkey), 14 handy tension band implants (TST, İstanbul, Turkey), and 14 medial malleolar anatomic plates (TST, İstanbul, Turkey) as well as and 84 screws (TST,

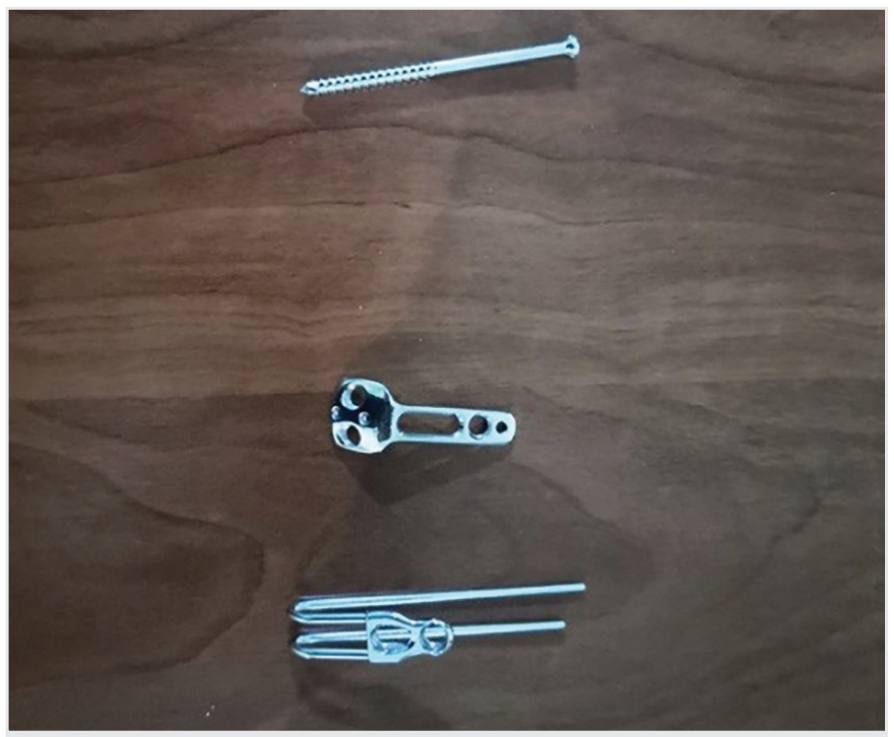

Figure 1. Implants used to fix fractures (left to right: malleolar screw, malleolar plate, and handy tension band)
İstanbul, Turkey) (Figure 1). The study was approved by Firat University Faculty of Medicine Non-Interventional Research Ethics Committee (approval number: 16, date: 03.10.2019). In total, 42 tibias from cows bred for human consumption were procured from a butcher and were cleared of soft tissue. Subsequently, the tibias were cut at $15 \mathrm{~cm}$ proximal to the tibial plafond, and the proximal segments were discarded. Then, transverse fractures were created on the medial malleoli of the bones using a bone saw, and the fractured bones were divided into three groups: Bones fixed using handy tension bands $(n=14)$, malleolar screws $(n=14)$, and medial malleolar plates $(n=14)$. All samples were then analyzed biomechanically using a test device (Shimadzu AG-X $50 \mathrm{kN}$, Japan) that could apply tensile and transverse forces. For this, we used an equipment designed specially to allow the attachment of the bones to the device and to provide axial loading in the metallurgical and materials engineering laboratory (Figure 2, 3). Tests were performed at $1 \mathrm{~mm} / \mathrm{min}$ for tensile force and $5 \mathrm{~mm} / \mathrm{min}$ for transverse force, with a preload of $20 \mathrm{~N}$ for the transverse force tests. Data from the test device were interpreted after being converting into force-displacement curves using the Trapezium X software (Shimadzu, Kyoto, Japan).

\section{Statistical Analysis}

The data were statistically analyzed using the IBM SPSS Statistics version 22.0 software package. Shapiro-Wilk test was used to determine whether the continuous measurements were normally distributed, and the data were presented as means \pm standard deviations. One-Way analysis of

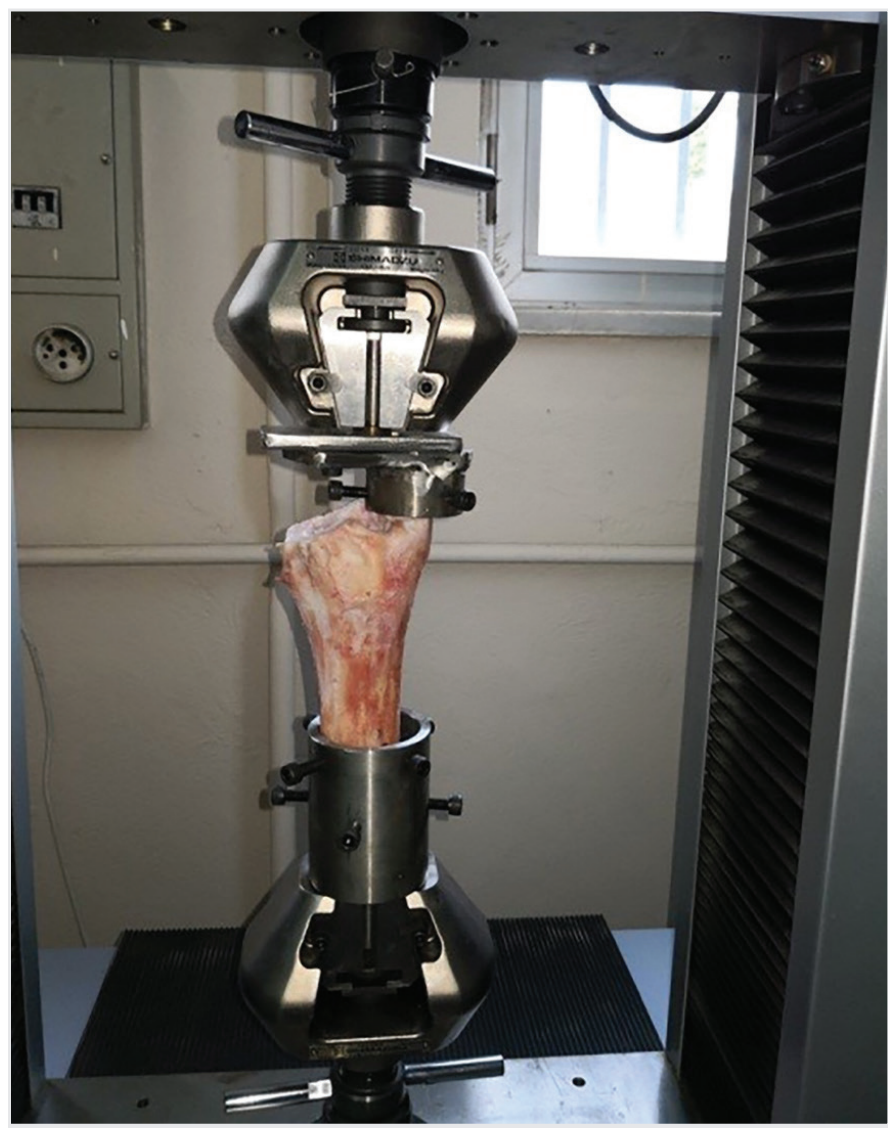

Figure 2. Application of tensile forces to the prepared samples 
variance was used to conduct an overall comparison of the continuous measurements of more than two groups. Among the groups, pairwise comparisons were made using Tukey's, Scheffe, and Tamhane tests, depending on the homogeneity of the within-group variance. The level of statistical significance was accepted as 0.05 for all analyses.

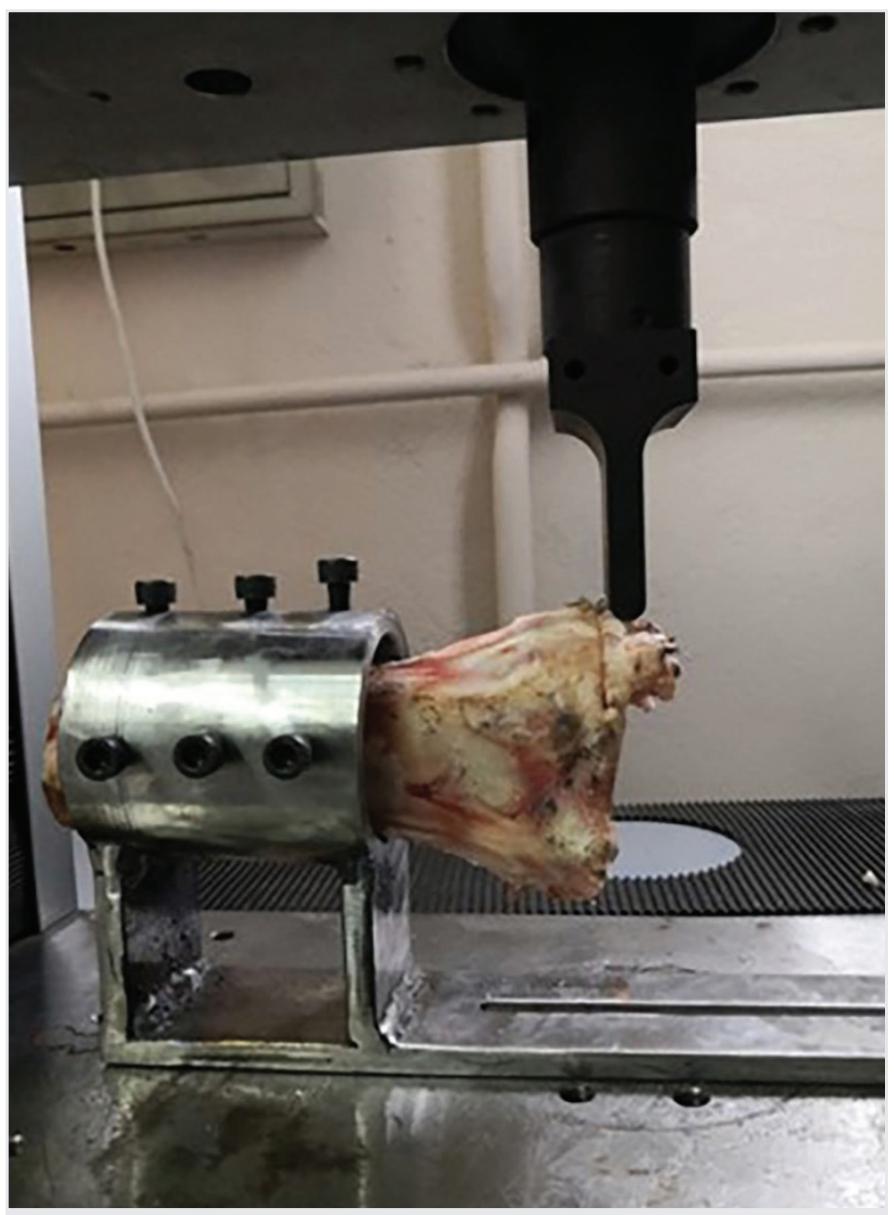

Figure 3. Application of transverse forces to the prepared samples

\section{Results}

Following application of transverse force, all three methods - malleolar screw, handy tension band, and medial malleolar plate-showed statistically significant differences in terms of such parameters as $2 \mathrm{~mm}$ displacement, catastrophic damage force, and resistance. Results of post-hoc analyses that were used to identify the relationship among the results of these three methods are provided in Table 1.

After the application of transverse force, the mean force required to create a $2 \mathrm{~mm}$ displacement was statistically significant in the malleolar plate group than the other fixation groups $(p<0.001)$. In addition, the $2 \mathrm{~mm}$ displacement force in the handy tension band group was significantly higher than that in the malleolar screw group $(p<0.001)$ (Table 1).

After the application of transverse force, the force required to create catastrophic damage was significantly higher in the medial malleolar plate group than in the malleolar screw group $(p<0.001)$. In addition, the mean force required to create irreversible damage was higher in the medial malleolar plate group than in the handy tension band group, albeit without statistical insignificance $(p=0.051)$. Under the same conditions, the handy tension band method was found to be superior to the malleolar screw method $(p=0.001)$ (Table 1).

After the application of transverse force, the malleolar plate group demonstrated significantly more resistant than the other two groups $(p<0.001)$, while the handy tension band group demonstrated greater resistance than the malleolar screw group $(p<0.02)$ (Table 1).

As with transverse force, application of tensile force also resulted in statistically significant differences in the parameters, and these differences were evaluated using post-hoc analyses (Table 1).

The medial malleolar plate group was compared with the malleolar screw and handy tension band groups in terms of the $2 \mathrm{~mm}$ displacement force. The medial malleolar plate group had significantly different 2 $\mathrm{mm}$ displacement force than the malleolar screw and handy tension band groups $(p<0.001)$. However, this parameter did not significantly

Table 1. Relationship between $2 \mathrm{~mm}$ displacement force, catastrophic damage force, and resistance following application of transverse and tensile forces*

\begin{tabular}{|c|c|c|c|c|c|c|c|c|c|c|c|}
\hline & & \multicolumn{5}{|c|}{ Transverse force } & \multicolumn{5}{|c|}{ Tensile force } \\
\hline & & Mean & SD & Min. & Max. & $\mathbf{p}$ & Mean & SD & Min. & Max. & p \\
\hline \multirow{3}{*}{$\begin{array}{l}2 \mathrm{~mm} \\
\text { displacement, } \\
\mathrm{N}\end{array}$} & Malleolar screw & $168.542^{\mathrm{a}}$ & 24.496 & 132.90 & 199.40 & \multirow{3}{*}{$<0.001$} & $1192.307^{a}$ & 193.022 & 829.40 & 1392.00 & \multirow{3}{*}{$<0.001$} \\
\hline & Tension band & $328.157^{b}$ & 30.096 & 287.70 & 372.40 & & $1188.571^{\mathrm{a}}$ & 158.774 & 916.60 & 1342.10 & \\
\hline & Malleolar plate & $758.628^{c}$ & 89.497 & 616.40 & 860.00 & & $1789.214^{b}$ & 205.869 & 1481.90 & 2048.30 & \\
\hline \multirow{3}{*}{$\begin{array}{l}\text { Catastrophic } \\
\text { damage, N }\end{array}$} & Malleolar screw & $3186.200^{\mathrm{a}}$ & 438.212 & 2458.70 & 3852.10 & \multirow{3}{*}{$<0.001$} & $1390.457^{a}$ & 248.503 & 980.40 & 1620.90 & \multirow{3}{*}{$<0.001$} \\
\hline & Tension band & $4705.985^{b}$ & 713.471 & 3842.70 & 5651.80 & & $1726.642^{b}$ & 223.046 & 1361.20 & 1983.20 & \\
\hline & Malleolar plate & $5574.757^{b}$ & 724.822 & 4549.30 & 6457.80 & & $2958.385^{c}$ & 222.162 & 2648.00 & 3285.40 & \\
\hline \multirow{3}{*}{$\begin{array}{l}\text { Resistance, } \\
\mathrm{N} / \mathrm{mm}\end{array}$} & Malleolar screw & $103.057^{a}$ & 12.524 & 87.40 & 122.20 & \multirow{3}{*}{$<0.001$} & $582.142^{a}$ & 65.558 & 473.40 & 654.70 & \multirow{3}{*}{0.001} \\
\hline & Tension band & $143.414^{b}$ & 10.628 & 127.50 & 156.00 & & $694.771^{a, b}$ & 135.242 & 509.20 & 847.00 & \\
\hline & Malleolar plate & $457.071^{c}$ & 40.346 & 387.40 & 512.10 & & $815.085^{b}$ & 57.941 & 752.80 & 914.10 & \\
\hline
\end{tabular}

"One-Way analysis of variance was performed, *a,b,c: shows that it is significantly different, *SD: standard deviation, Min.: minimum, Max.: maximum, N: Newton, mm: millimeter, p<0.05 indicates statistical significance 
differ between the handy tension band group and the malleolar screw group ( $p=0.999$ ). The tensile force required for catastrophic damage was significantly higher in the medial malleolar plate group than in the malleolar screw and tension band groups $(p<0.001)$.

Following the application of tensile force, a mean difference of 120.3 $\mathrm{N} / \mathrm{mm}$ in resistance was noted between the medial malleolar plate and handy tension band groups, although the difference was not statistically significant $(p=0.065)$. In contrast, the medial malleolar plate method was found to be significantly more resistant than the malleolar screw method $(p=0.001)$.

\section{Discussion}

Several fixation methods have been reported for the surgical treatment of medial malleolar fractures. One of the most common methods involves the use of two $4 \mathrm{~mm}$ partially-threaded cancellous screws, inserted parallel to each other, and perpendicular to the fracture line. However, in case of small fragment fractures, which cannot be fixed with screws, the tension band method may be preferred. The buttress plates used for vertical fractures of the medial malleolus are not an appropriate implant option in transverse fractures $(7,8)$. Mini-fragment plates might be an alternative approach for the surgical treatment of small fragment non-vertical fractures (9).

Locking plates may be promising for treating medial malleolar fractures owing to the angular stability they provide and the conversion of shear forces into compression forces (10). Previous studies have reported on the superiority of supporting plates over other methods for use in vertical fractures of the medial malleolus; however, studies regarding the use of locking plates in medial malleolar fractures are limited in number $(11,12)$.

Amanatullah et al. (13) used composite synthetic bone models (Sawbones) to create medial malleolar osteotomies in such models, with fixation provided by malleolar screws, a traditional tension band, and properly contoured, mini-fragment T-plates. The malleolar screw group was divided into parallel and divergent subgroups to examine the two types of fixation. After fixation, all groups were exposed to tensile force, and then, resistance and $2 \mathrm{~mm}$ displacement forces were measured. The plate-fixation group demonstrated significantly more resistance than the other group in terms of resistance and $2 \mathrm{~mm}$ displacement forces. The authors identified no significant difference in the $2 \mathrm{~mm}$ displacement and resistance forces among the other groups. The present study found that the medial malleolar plate approach was significantly superior to other methods in terms of $2 \mathrm{~mm}$ displacement forces after the application of tensile force; however, the difference in resistance between the medial malleolar plate and handy tension band groups was not statistically significant. The medial malleolar plate approach was more resistant than the malleolar screw method.

Amanatullah et al. (13) used a traditional tension band and contoured mini-fragment T-plates; however, in the present study, we used a handy tension band system and a medial malleolar plate. The plate used in the present study was manufactured for compatibility with the medial malleolar area and therefore did not require contouring. Amanatullah et al. (13) suggested that the plate used in their study would not cause skin irritation, as it was small and shaped to be fully compatible with the medial malleolar area. However, clinical studies are required to support this claim

In their study, Wegner et al. (14) conducted transverse medial malleolar osteotomies on Sawbones models, with tensile force applied to the handy tension band and malleolar screw to evaluate resistance, 2 $\mathrm{mm}$ displacement, and catastrophic damage forces, similar to the present study. The authors found that the handy tension band system was significantly superior to the malleolar screw system in all three parameters. After the application of tensile force, the screws remained in the distal tibial area and with no screws in the malleolar area in the malleolar screw group. However, the screws broke loose from the distal tibia, and the malleolar area remained in the system in the handy tension band group. In the present study, the screws remained stable, while the malleolar area parted from the system in both the groups

Implant irritation after the surgical treatment of medial malleolar fractures is a relatively common problem owing to the small amount of soft tissue coverage in this area $(15,16)$. It is vital that in addition to providing stability, the material used to fix the fracture does not cause skin problems. Jiang et al. (17) designed a locking compression plate that was anatomically appropriate for the medial malleolar area. It featured a thinner profile on the distal side than on the proximal side (proximal thickness: $2 \mathrm{~mm}$, distal thickness: $1 \mathrm{~mm}$ ) and conducted a biomechanical study to compare the system with the malleolar screw approach. To this end, the authors created transverse, oblique, and vertical medial malleolar fractures through cuts at various angles on synthetic bones. Subsequently, they fixed such fractures with their plate and the malleolar screw system. Forces of 300-500 N and $700 \mathrm{~N}$ were applied to groups, and the plate was found to have a superior resistance in all fracture types compared with the malleolar screw, and this superiority was observed to be more apparent in vertical fractures than in the other fracture types. The authors further fixed the stress points on the plate and screw under loading but observed no increased stress density in the thinner distal part of the plate, and reported this finding a positive outcome for implant failure. The plate used in the present study was a medial malleolar curved locking compression plate with similar proximal and distal thickness $(2 \mathrm{~mm})$. Similar to the study by Jiang et al. (17), the present study found that the malleolar plate provided significantly greater resistance than the screw when transverse force was applied. Jiang et al. (17) assumed that transverse fractures could be fixed by adequate stabilization with screws, while suggesting plates in oblique and vertical fractures; however, their study was limited by the application of only adduction forces.

Owing to implant irritation, implant-related pain, and the associated need for secondary surgery requiring implant removal, researchers have been investigating various available implant models. Clyde et al. (18) conducted a biomechanical study on their knotless tension band to compare their method with the traditional tension band; they concluded that the knotless tension band was superior regarding certain criteria, such as $2 \mathrm{~mm}$ displacement, catastrophic damage force, and resistance. In a study by Fowler et al. (19), the bicortical screw, unicortical screw, traditional tension band, and fiber-wire tension band systems were compared. The screw groups were exposed to axial, transverse, and 
tensile forces, whereas the tension band groups were exposed only to tensile forces to evaluate the $2 \mathrm{~mm}$ displacement force, catastrophic damage force, and resistance, in line with the present study. Among the bicortical and unicortical screw groups, the former was significantly superior in terms of $2 \mathrm{~mm}$ displacement force and catastrophic damage force when both transverse and tensile forces were applied. In the tension band groups, the traditional tension band was superior in resistance-catastrophic damage force, while there was no difference in $2 \mathrm{~mm}$ displacement force between the two groups. Regarding resistance against tensile force, the bicortical screw method was the most resistant, while the unicortical screw group had the lowest resistance. The present study compared the unicortical screw and handy tension band, but identified no significant difference in resistance against tensile forces between the two methods.

Few previous studies have suggested that the tension band implant is more appropriate for avulsion fractures that cannot be fixed with osteoporotic bones and screws $(20,21)$. Nevertheless, the traditional tension band application may result in complications, such as skin problems and painful implants, which would require implant removal. In such cases, Fowler and Clyde indicate using fiber-wire tension bands, suggesting that this will minimize complications. The present study found the plate-fixation approach to be superior for most parameters examined, although there were no findings supporting the ability of this method to minimize complications.

A retrospective study by Maniar et al. (22) enrolled 85 patients and evaluated the outcomes of medial malleolar fractures treated with handy tension bands $(n=21)$ and malleolar screws $(n=64)$, examining parameters such as the time of union, radiological solid union, implant failure, implant removal, and visual analog scale (VAS) score. However, they found no significant differences between the two groups. Based on this finding, the authors suggested that the malleolar screw method was more appropriate considering cost, recovery rates, and complications, although they reported the low number of patients as a limitation and expressed the need for a similar study involving a larger population. A retrospective study conducted in our country by Bulut and Gursoy (23) with 32 patients assessed the outcomes of treatment with tension bands, malleolar screws, and fully threaded headless compression screws among patients with medial malleolar fractures. The authors evaluated parameters such as medial sensitivity, time of union, VAS score, American Orthopaedic Foot and Ankle Society (AOFAS) score, and implant removal. The authors found no significant differences between the two groups regarding the time of union and AOFAS scores. Implant removal resulting from implant irritation was not observed in the headless cannulated screw group. However, two patients in the malleolar screw group and three in the tension band group underwent implant removal.

A previous study evaluating the bicortical screw method for treating medial malleolar fractures discussed the importance of fixation among patients with risk factors for fracture union as well as underlined the target of early mobilization through bone stabilization (24). Reportedly, comorbidities such as advanced age, diabetes, renal failure, osteoporosis, and peripheral artery diseases can negatively affect surgical outcomes, can increase the rate of revision surgeries, and can prolong immobilization time, with associated increases in treatment costs $(25,26)$. Notably, a limited number of studies have assessed the use of plates for fixing medial malleolar fractures.

Under transverse force, the medial malleolar plate method was superior to the malleolar screw and handy tension band methods in terms of $2 \mathrm{~mm}$ displacement force and resistance, although there was no significant difference in the catastrophic damage force between the medial malleolar plate and handy tension band methods. The medial malleolar plate method was resistant to greater catastrophic damage forces than the malleolar screw.

Under tensile force, the medial malleolar plate method proved significantly superior to the malleolar screw and handy tension band methods in terms of $2 \mathrm{~mm}$ displacement and catastrophic damage forces. Although there was no significant difference in resistance between the plate and the handy tension band methods, the medial malleolar plate was more resistant than the malleolar screw.

\section{Study Limitations}

One limitation of our study is the in vivo design, which prevented the evaluation of complications. Another limitation is that the variables relating to the sourced animal bones (e.g., age and sex) could not be identified

\section{Conclusion}

We concluded that the medial malleolar plate approach is appropriate for transverse fractures of the medial malleolus; however, further research is needed to identify the potential disadvantages of this method. Although our study demonstrated the biomechanical superiority of fixation with a plate compared with fixation with handy tension bands and malleolar screws in several parameters, we believe that clinical studies are needed to investigate complications related to the use of this fixation method in ankle fractures with comorbidities.

Ethics Committee Approval: The study was approved by Firat University Faculty of Medicine Non-Interventional Research Ethics Committee (approval number: 16, date: 03.10.2019).

Informed Consent: It wasn’t obtained.

Peer-review: Externally and internally peer-reviewed.

Authorship Contributions: Concept - G.Y., M.G.; Design - S.D., Y.S.; Supervision - S.D., Y.S.; Resources - G.Y., S.K., A.S.; Materials - G.Y., Y.S.; Data Collection or Processing - S.K., A.S.; Analysis or Interpretation - S..D., Y.S.; Literature Search - G.Y., S.K., A.S.; Writing - G.Y., M.G.; Critical Review - M.G., S.D.

Conflict of Interest: No conflict of interest was declared by the authors.

Financial Disclosure: It was financially supported by the Firat University Scientific Research Project.

\section{References}

1. Vander Griend R, Michelson JD, Bone LB. Instructional course lecture: fractures of the ankle and the distal part of the tibia. J Bone Joint Surg 1996; 78: $1772-83$ 
2. Timothy TH, Duckworth AD, White TO. Medial malleolar fractures: current treatment concepts. Bone Joint J 2019; 101: 512-21.

3. Ebraheim NA, Weston JT, Ludwig T, Moral MZ, Carroll T, Liu J. The association between medial malleolar fracture geometry, injury mechanism, and syndesmotic disruption. Foot Ankle Surg 2014; 20: 276-80.

4. Meinberg EG, Agel J, Roberts CS, Karam MD, Kellam JF. Fracture and Dislocation Classification Compendium-2018. J Orthop Trauma 2018; 32(Suppl1): S1-170.

5. Yablon IG, Heller FG, Shouse L. The key role of the lateral malleolus in displaced fractures of the ankle. J Bone Joint Surg Am 1977; 59: 169-73.

6. Herscovici D, Scaduto JM, Infante A. Conservative treatment of isolated fractures of the medial malleolus. J Bone Joint Surg Br 2007; 89: 89-93.

7. Dumigan RM, Bronson DG, Early JS. Analysis of fixation methods for vertical shear fractures of the medial malleolus. J Orthop Trauma 2006; 20: 687-91.

8. Toolan BC, Koval KJ, Kummer FJ, Sanders R, Zuckerman JD. Vertical shear fractures of the medial malleolus: a biomechanical study of five internal fixation techniques. Foot Ankle Int 1994; 15: 483-9.

9. Amanatullah DF, Wolinsky PR. An alternative fixation technique for small medial malleolus fractures. Orthopedics 2010; 33: 888-9.

10. Christoph Sommer. Locking plates. In: Ruedi TP, Murphy WM (eds). AO Principles of Fracture Management, 3rd ed., Stuttgart, Germany: Thieme; 2017: pp. 269-308.

11. Wegner AM, Wolinsky PR, Robbins MA, Garcia TC, Maitra S, Amanatullah DF. Antiglide plating of vertical medial malleolus fractures provides stiffer initial fixation than bicortical or unicortical screw fixation. Clin Biomech 2016; 31 : 29-32.

12. Blake S, Yakubek G, Shaer J. Use of a Locked Fibular Plate for Fixation of a Vertical Shear Medial Malleolus Fracture: A Case Report. J Foot Ankle Surg 2015; 54: 1202-5.

13. Amanatullah DF, McDonald E, Shellito A, Lafazan S, Cortes A, Curtiss S, et al. Effect of mini-fragment fixation on the stabilization of medial malleolus fractures. J Trauma Acute Care Surg 2012; 72: 948-53.

14. Wegner AM, Wolinsky PR, Cheng RZ, Robbins MA, Garcia TC, Amanatullah DF. Sled fixation for horizontal medial malleolus fractures. Clin Biomech 2017; 42: 92-6.
15. Minkowitz RB, Bhadsavle S, Walsh M, Egol KA. Removal of painful orthopaedic implants after fracture union. J Bone Joint Surg Am 2007; 89: 1906-12.

16. Brown OL, Dirschl DR, Obremskey WT. Incidence of hardware-related pain and its effect on functional outcomes after open reduction and internal fixation of ankle fractures. J Orthop Trauma. 2001; 15: 271-4.

17. Jiang D, Zhan S, Wang Q, Ling M, Hu H, Jia W. Biomechanical Comparison of Locking Plate and Cancellous Screw Techniques in Medial Malleolar Fractures: A Finite Element Analysis. J Foot Ankle Surg 2019; 58: 1138-44.

18. Clyde J, Kosmopoulos V, Carpenter BA A biomechanical investigation of a knotless tension band in medial malleolar fracture models in composite Sawbones $^{\circledR}$. J Foot Ankle Surg 2013; 52: 192-4.

19. Fowler TT, Pugh KJ, Litsky AS, Taylor BC, French BG. Medial malleolar fractures: a biomechanical study of fixation techniques. Orthopedics 2011; 34: 349-55.

20. Georgiadis GM, White DB. Modified tension band wiring of medial malleolar ankle fractures. Foot Ankle Int 1995; 16: 64-8.

21. Johnson BA, Fallat LM. Comparison of tension band wire and cancellous bone screw fixation for medial malleolar fractures. J Foot Ankle Surg 1997; 36: 2849.

22. Maniar H, Kempegowda H, Tawari AA, Rutter MR, Borade A, Cush G, et al. Medial Malleoli Fractures: Clinical Comparison Between Newly Designed Sled Device and Conventional Screws. Foot Ankle Spec 2017; 10: 296-301.

23. Bulut T, Gursoy M. Isolated Medial Malleolus Fractures: Conventional Techniques Versus Headless Compression Screw Fixation. J Foot Ankle Surg 2018; 57: 552-6.

24. King CM, Cobb M, Collman DR, Lagaay PM, Pollard JD. Bicortical fixation of medial malleolar fractures: a review of 23 cases at risk for complicated bone healing. J Foot Ankle Surg 2012; 51: 39-44.

25. Kadakia RJ, Ahearn BM, Schwartz AM, Tenenbaum S, Bariteau JT. Ankle fractures in the elderly: risks and management challenges. Orthop Res Rev 2017; 9: 45-50

26. Strauss EJ, Egol KA. The management of ankle fractures in the elderly. Injury 2007; 38(Suppl3): \$2-9. 